\title{
A HUMANE APPROACH CAN WORK: \\ THE EFFECTIVENESS OF ALTERNATIVES TO DETENTION FOR ASYLUM SEEKERS
}

By Mark Noferi, Esq. 


\section{A HUMANE APPROACH CAN WORK: THE EFFECTIVENESS OF ALTERNATIVES TO DETENTION FOR ASYLUM SEEKERS}

\section{ABOUT THE AUTHOR}

Mark Noferi, Esq. is the Enforcement Fellow at the American Immigration Council. His research focuses on enforcement, detention, due process, and criminalimmigration connections. Mark was formerly a visiting associate fellow at the Center for Migration Studies of New York, and taught civil rights and immigration at Brooklyn Law School and the Seton Hall Law School Center for Social Justice. Mark clerked for the Hon. Harold Baer, Jr. in the Southern District of New York. Mark earned his J.D. from Stanford Law School and B.A. from Boston College.

\section{ABOUT THE AMERICAN IMMIGRATION COUNCIL}

The American Immigration Council's policy mission is to shape a rational conversation on immigration and immigrant integration. Through its research and analysis, the Immigration Council provides policymakers, the media, and the general public with accurate information about the role of immigrants and immigration policy in U.S. society. Our reports and materials are widely disseminated and relied upon by press and policymakers. Our staff regularly serves as experts to leaders on Capitol Hill, opinion-makers, and the media. We are a non-partisan organization that neither supports nor opposes any political party or candidate for office.

Visit our website at www.AmericanImmigrationCouncil.org and our blog at www.immigrationimpact.com.

\section{ABOUT THE CENTER FOR MIGRATION STUDIES}

The Center for Migration Studies of New York (CMS) is an educational institute/ think tank devoted to the study of international migration, to the promotion of understanding between immigrants and receiving communities, and to public policies that safeguard the dignity and rights of migrants, refugees and newcomers (www.cmsny.org). CMS was established in 1964 and formally incorporated in 1969 by the Congregation of the Missionaries of St. Charles, Scalabrinians, an international community of Catholic priests, nuns and lay people dedicated to serving migrants and refugees. CMS is a member of the Scalabrini International Migration Network (SIMN), a global network of more than 270 entities that provide services to migrants, including shelters along migrant corridors and welcoming (integration) centers in receiving communities. 
1 INTRODUCTION

2 EVIDENCE INDICATES THAT ASYLUM SEEKERS PROVIDED ALTERNATIVES TO DETENTION AND LEGAL ASSISTANCE WILL COMPLY WITH PROCEEDINGS

\section{Contents}

6 DETENTION HAS SERIOUS ADVERSE CONSEQUENCES FOR ASYLUM SEEKERS

9 THE GOVERNMENT SHOULD TAKE STEPS TO REDUCE THE DETENTION OF ASYLUM SEEKERS AND INCREASE ACCESS TO COUNSEL 


\section{Introduction}

For decades, the U.S. refugee protection system has been a symbol of the nation's generosity and openness to the world's persecuted. ${ }^{1}$ Yet since Congress' enactment of the Illegal Immigration Reform and Immigrant Responsibility Act of 1996 (IIRIRA), asylum seekers arriving at the United States-Mexico border have been subject to mandatory detention and summary deportation processes, ${ }^{2}$ resulting in the deportation of countless persons in need of protection. ${ }^{3}$

Empirical research has found, however, that asylum seekers fleeing persecution arrive predisposed to comply with legal processes and trust the system to provide them a fair hearing, even if they might lose. ${ }^{4}$ If the U.S. government treats asylum seekers fairly and humanely-i.e., releases them following their apprehension and provides legal assistance before their hearing-evidence suggests that they will be likely to appear for proceedings. Put simply, a humane approach can work.

This report reviews emerging research on the release of asylum seekers from detention, including the impact of various forms of alternatives to detention (ATD), summarizes the primary harms caused by immigration detention, and argues that releasing asylum seekers (on alternatives as needed) and affording legal assistance can protect the rights of asylum seekers and facilitate compliance with proceedings and legitimate removals, at far less human and financial cost than detention. ${ }^{5}$ 


\section{Evidence Indicates That Asylum Seekers Provided Alternatives to Detention and Legal Assistance Will Comply with Proceedings}

For years, quantitative studies have showed that asylum seekers comply with proceedings (i.e., appear for interviews and court hearings) at high rates. But increasingly, qualitative researchers, primarily outside the United States, have begun examining the reasons for compliance and identified best practices for use in the field. This qualitative research builds upon psychological research showing that when someone in a legal proceeding feels he or she is treated fairly, that person is more likely to view the proceeding as legitimate, and in turn be more likely to appear for hearings and comply with the results of the proceeding. ${ }^{6}$

\section{Studies of Alternatives to Detention Show High Rates of Compliance with Proceedings}

Studies since 1996 have showed very high rates of compliance with proceedings by asylum seekers who were placed into alternatives to detention (a.k.a. "ATD" or supervised release). ${ }^{7}$ A 2000 study, commissioned by the U.S. government and conducted by the Vera Institute of Justice, reported an 83 percent rate of compliance with court proceedings among asylum seekers who were found to have a credible fear in the expedited removal process. The study also showed a compliance rate of 84 percent among asylum seekers who were under minimal supervision, and 78 percent among those simply released without supervision. ${ }^{8}$ The Vera Institute concluded that "[a]sylum seekers do not need to be detained to appear.... They also do not seem to need intensive supervision." "Likewise, Canada's Toronto Bail Program, which uses more restrictive supervision, reported a "lost client" ratio among refugee claimants of 8.42 percent from 2002 to $2003 .^{10}$

Alternatives to detention programs not exclusively involving asylum seekers also have shown extremely high rates of compliance. With respect to the U.S. Immigration and Customs Enforcement (ICE) Intensive Supervision Appearance Program (ISAP), from fiscal years 2011 to 2013, 95 percent of participants in the "full-service" program appeared at their scheduled removal hearings, ${ }^{11}$ far exceeding ICE's FY 2010 target for appearance rates by 37 percent. ${ }^{12}$ Various Australian alternatives to detention program pilots have achieved 94 percent compliance across programs. ${ }^{13}$ 


\section{Asylum Seekers Are Especially Predisposed to Comply with Removal Proceedings}

Qualitative research has provided an explanation for these high success rates by demonstrating that asylum seekers are especially predisposed to comply with proceedings. According to a UNHCR-sponsored 2013 study of asylum seekers in Toronto and Geneva, asylum seekers possess a "cooperative predisposition" which derives from four factors. ${ }^{14}$

First, the "refugee predicament" and fear of persecution "looms largest" in providing a "strong inducement to comply." 15 Most interviewees felt they had no choice but to comply with legal processes in order to protect themselves from further persecution. ${ }^{16}$ Asylum seekers spoke of their "lack of a Plan B" or the "impossibility of returning home." 17

Second, asylum seekers have a natural "inclination towards law-abidingness." 18 Many expressed that "making the refugee claim was a manifestation of faith in legal process." ${ }^{19}$ Indeed, asylum seekers "strongly value the rule of law," since many "fled nations with substantial rule of law deficiencies." 20

Third, asylum seekers are inclined to trust the process of determining their claim, and perceive it as fair. Significant numbers of Toronto and Geneva asylum seekers expressed that they expected to enter a "safe haven... where human rights were protected." ${ }^{21}$ Asylum seekers also understood that their claim might not succeed. But they "expected not automatic protection, but a fair hearing." 22

Fourth, asylum seekers have a strong desire to "avoid irregular residence," and most prominently detention, with its attendant hardships. ${ }^{23}$ (The Vera Institute also found that for U.S. asylum seekers released on supervision, avoiding detention was a primary motivator for them to comply with supervision terms. ${ }^{24}$ )

\section{Legal Assistance, Without Detention, Fosters Compliance with Removal Proceedings}

Research on asylum seekers has found that access to early, reliable legal advice is the single most important factor in fostering trust in the legal system and, as a result, ensuring compliance with the adjudicatory process. ${ }^{25}$ For example, as one asylum seeker in Toronto said after receiving legal advice, "It is crazy but yeah, I do have trust in the system because I understand it." ${ }^{26}$ Although asylum seekers arrive predisposed to comply with legal processes, compliance is a combination of "knowing the right thing to do and wanting to do it." ${ }^{27}$ And knowing the "right thing to do" requires sound legal advice, especially for asylum seekers who are often 
confused by the removal process. ${ }^{28}$ Legal assistance can make an asylum-seeker aware that he or she may be eligible for relief, and thus make it more likely that he or she will appear at proceedings. ${ }^{29}$

A lawyer or case worker can most effectively foster trust by identifying and discussing all possibilities with a client early on, even if relief initially appears unattainable, in order to help a client understand the system and feel heard. ${ }^{30}$ The Vera Institute reported that many asylum seekers attended their hearings because they "felt they had someone on their side during the court process." 31

Although data is not yet available for adults, historical U.S. data on children in immigration proceedings suggests that legal assistance can help to ensure compliance. Over a period of more than nine years, 92.5 percent of those children represented by lawyers appeared for their removal hearings, versus 27.5 percent of children not represented by lawyers. ${ }^{32}$

\section{Holistic Government Assistance, Without Detention, Also Fosters Compliance with Removal Proceedings and Potentially Removal Orders}

Government support to asylum seekers-particularly legal assistance, but also social services and housing assistance-also may foster a sense of "belonging" that encourages them to appear for proceedings. ${ }^{33}$ For example, Toronto asylum seekers who were placed in residences rather than detention, with access to legal assistance and caseworkers, displayed a "remarkable degree of affection towards Canada" and felt "part of Canadian society." ${ }^{44}$ The researchers found this to be a "strong factor supporting cooperation" with the authorities. ${ }^{35}$

The Vera Institute also found that its U.S. caseworker assistance-which included information on court processes and supervision conditions, referrals to low-cost legal representation, and health, educational, and social services ${ }^{36}$-gave participants a "sense of belonging to life in the United States," and made them more "willing to buy into cooperation and compliance." ${ }^{37}$ Participants in the Vera program particularly emphasized the program staff's "kindness and decent treatment" to them, which included "a willingness to take the time to listen and offer constructive guidance." 38 Vera found that responding to needs as basic as "somewhere to go or someone to call for assistance" contributed the most to a sense of belonging. ${ }^{39}$ Subsequently, many Vera program participants expressed that they appeared at their proceedings out of a sense of obligation and gratitude to their caseworkers. ${ }^{40}$

Asylum seekers' compliance also may be independent of any community ties in the United States, a factor ICE uses to evaluate flight risk. An asylum seeker's fear of being returned to persecution, and sense of belonging if provided assistance, may 
incentivize him or her to comply with proceedings even if the individual knows no one in the United States. ${ }^{41}$ Therefore, ICE's current detention risk evaluation, which considers the lack of family or a potential address in the United States to be factors supporting detention, ${ }^{42}$ may overestimate the flight risk posed by asylum seekers in immigration proceedings.

Lastly, providing assistance to asylum seekers may further their compliance with removal orders, although further research is necessary on this point. UNHCR researchers found that "early access to trusted advice and support... may help maintain the rejected asylum-seeker's cooperation with the authorities, even if the claim is rejected." "43 The Vera Institute also found, albeit for a small sample size, that asylum seekers "comply at very high rates" with removal orders. ${ }^{44}$ Vera theorized that assistance may facilitate compliance with a removal order; Vera program participants made points like, "Although I thought the case was not in my favor, I made an obligation to [my caseworkers] and I did not want to let them down." ${ }^{45}$ Vera also found that those who complied with removal orders expressed a desire to one day return legally to the United States if possible. ${ }^{46}$ 


\section{Detention Has Serious Adverse Consequences for Asylum Seekers}

Conversely, the adverse impacts of detention upon the vulnerable population of asylum seekers are widely recognized and documented, and include psychological harm, interference with access to legal assistance, and even abandonment of legitimate asylum claims. Given these deleterious effects in a context where a wrong decision can return a person to serious harm or death, it is imperative that ICE explore alternatives, including release on recognizance or on bond, parole, or enrollment in a supervised release program.

\section{Detention Causes Psychological Harm}

Detention facilities for asylum seekers in the United States have been roundly criticized as unnecessarily punitive and abusive. ${ }^{47}$ Border Patrol short-term facilities often are overcrowded. In addition, detainees regularly endure verbal and physical abuse, lack of adequate food and water, unhygienic conditions, and temperatures so low as to pose a health risk. ${ }^{48}$ For longer-term detention, ICE uses secure facilities (including criminal jails), ${ }^{49}$ unlike "open" facilities that allow detainees to leave and return to the facility such as those used by some European countries for asylum seekers. ${ }^{50}$

The detention of asylum seekers in a secure facility for an undefined period causes psychological and physical trauma. Detainees confined under these terms have little information or control over their confinement and often experience circumstances similar to "sensory deprivation." 51 They develop feelings of "helplessness and hopelessness that lead to debilitating depressive symptoms, chronic anxiety, despair, dread," and "PTSD [Post-Traumatic Stress Disorder] and suicidal ideation." ${ }^{2}$

A 2003 comprehensive study of 70 asylum seekers in U.S. detention facilities by Physicians for Human Rights (PHR) and Bellevue Hospital found that 86 percent experienced symptoms of depression, 77 percent anxiety, and 50 percent PTSD. ${ }^{53}$ Moreover, Physicians for Human Rights has found that asylum seekers are particularly vulnerable to trauma, because detention exacerbates past traumas that many have experienced. ${ }^{54}$ International studies reinforce and complement those findings. For example, immigration detainees in secure Swedish facilities reported that "detention is worse than prison because in prison at least the outcome and the time period are known." ${ }^{55} \mathrm{~A}$ Canadian study also found increased rates of posttraumatic stress and depression among detained versus non-detained asylum seekers. ${ }^{56}$ And although U.S. studies on recent Central American asylum seekers have not yet been conducted, several women have attempted suicide, ${ }^{57}$ and many have launched hunger strikes ${ }^{58}$ and protests. ${ }^{59}$ 
Notably, Physicians for Human Rights also reported that the traumas from undefined detention "appear to be independent of the conditions of detention." ${ }^{60}$ For example, even though Swedish secure facilities are operated by staff without uniforms and offer recreational, educational and other activities, researchers still found that indefinite detention posed a "huge threat" to detainees' "health and wellbeing." 61 Recently, non-governmental organizations (NGOs) filed a civil rights complaint asking the U.S. Department of Homeland Security (DHS) to investigate several cases of psychological trauma within family detention. ${ }^{62}$ In short, the evidence suggests that while conditions of detention must be improved, ${ }^{63}$ improving detention conditions alone is not enough to prevent harm to asylum seekers.

\section{Detention Impedes Access to Legal Assistance}

The U.S. government does not provide a lawyer to those seeking asylum. ${ }^{64}$ Moreover, detention makes it unlikely that asylum seekers can afford or otherwise secure a lawyer. Many detention centers are located in remote locations, far from pro bono immigration lawyers. ${ }^{65}$ Some have restrictive access policies that inhibit effective pro bono representation. ${ }^{66}$ Detention also makes it difficult to collect evidence, especially without a lawyer. ${ }^{67}$

Yet, representation is crucial: studies show that a lawyer makes a real difference in whether a person will succeed in his or her asylum case. In a 2007 national study, 45.6 percent of represented asylum seekers in formal removal proceedings were successful, compared to 16.3 percent of unrepresented asylum seekers. ${ }^{68}$ Similarly, in New York, 84 percent of represented individuals who brought persecutionbased claims in immigration court were successful, compared to 21 percent of unrepresented individuals who brought persecution-based claims. ${ }^{69}$

Such results are not surprising. A lawyer can play a key role in helping the asylum seeker navigate legal and procedural complexities, collecting evidence, and advocating for him or her to decision makers. Many asylum seekers are afraid to talk to U.S. government officials, ${ }^{70}$ which inhibits their already-limited ability to advocate for themselves. If the asylum officer determines that an asylum seeker fears return, he or she must still negotiate trial-like removal proceedings against a government lawyer. Often the asylum seeker has little education or ability to speak or understand English and is without friends or family to help prepare her claims. ${ }^{71}$ Judges review asylum seekers' statements for exacting consistency and may deny relief based on an inconsistency. ${ }^{72}$ 


\section{Detention Causes Abandonment of Asylum Claims}

Detention without legal assistance also leads some to abandon their asylum applications despite having a credible fear of persecution or torture. ${ }^{73}$ In a major study of asylum seekers in expedited removal, the U.S. Commission on International Religious Freedom (USCIRF) interviewed 45 asylum seekers who abandoned their asylum claims while in detention and found that a "substantial number reported that the conditions of their detention influenced their decision to withdraw their application for admission." ${ }^{4}$ The same study found that over a five-year period, detained credible fear claimants withdrew their asylum claims in immigration court at more than double the rate of non-detained or released claimants (13 percent versus five percent). ${ }^{75}$

Additionally, in FY 2014, USCIS "closed" a much higher number of applications due to withdrawal or abandonment in reinstatement of removal proceedings (46 percent) than in expedited removal proceedings (10 percent). ${ }^{76}$ Although USCIS did not report its reasons for closing, applicants in reinstatement of removal proceedings have been detained much longer on average pending USCIS' decision. ${ }^{77}$ 


\section{The Government Should Take Steps to Reduce the Detention of Asylum Seekers and Increase Access to Counsel}

Taken together, the available research suggests that if the U.S. government treats asylum seekers fairly and humanely, they will likely appear for proceedings. Particularly given the serious adverse effects of detention on asylum seekers, immediate steps should be taken to reduce detention and ensure access to legal assistance. The Center for Migration Studies and U.S. Conference of Catholic Bishops have provided detailed recommendations to implement these goals, with a particular focus on asylum seekers. ${ }^{78}$ The immigration reform bill that passed the Senate in 2013 also contained several positive steps towards these goals. ${ }^{79}$

NGOs have uniformly recommended that the practice of detaining families be ended. ${ }^{80}$ Recently, DHS Secretary Jeh Johnson announced the agency's intention to shorten detention for initial processing for families, ${ }^{81}$ and ICE subsequently released some mothers and children who had been determined to have a credible fear of returning to their countries. ${ }^{82}$ Both are positive first steps.

Generally, release should be the norm, not detention. ICE can and should expand its use of release on recognizance, bond, and parole, with alternatives to detention only provided to those needing it to appear for proceedings. Notably, ICE's use of alternatives to detention-generally, supervision, tracking, and case managementhas been limited compared to ICE's use of detention. ICE's Intensive Supervision Appearance Program (ISAP), which is managed by a for-profit contractor, supervised 40,864 noncitizens in FY 2013, compared to 440,557 noncitizens that ICE detained..$^{83}$ ICE sometimes uses ISAP for asylum seekers initially placed in expedited removal who have been screened and found to have a credible fear. ${ }^{84}$ Specific statistics on asylum seekers enrolled in ISAP are unavailable, however.

The level of restriction placed on a person in ISAP varies. In FY 2013, ISAP placed GPS (i.e., electronic tracking bracelets or "ankle bracelets") on 48 percent of the noncitizens in its "full-service" program, while it subjected the remaining 52 percent only to telephonic check-ins. ${ }^{85}$ Recent reports, however, indicate that ICE is increasingly using ankle bracelets on asylum seekers. ${ }^{86}$ Yet ankle bracelets are intrusive, stigmatizing, and in some cases cause retraumatization and often are unnecessary. ${ }^{87}$ Given that asylum seekers are predisposed to comply with their legal proceedings, this form of intensive supervision is rarely needed. As one mother recently forced to wear an ankle bracelet said, "Where do they think I'm going to flee to? I have nowhere to go." ${ }^{8}$ 
ICE also has intermittently engaged NGOs to facilitate community supervision pilot programs-i.e., case management and assistance services provided by an NGO, rather than a for-profit entity such as ICE's current contractor. ${ }^{89}$ In February 2015, ICE announced its intention to fund community-based case management services for families in five major metropolitan areas. ${ }^{90}$ This is a positive step, particularly considering the concerns that for-profit detention management has raised. ${ }^{91}$

Reducing unnecessary detention not only would minimize human costs, but would reduce the financial burden of detention as well. ICE's ATD programs cost $\$ 10.55$ per day, as opposed to detention, which costs $\$ 158$ per day. ${ }^{92}$ Yet the Obama administration requested only $\$ 122.5$ million for ATDs in FY 2016, as part of a total detention budget of $\$ 2.4$ billion..$^{93}$ The $\$ 435$ million requested for family detention alone dwarfs the requested ATD budget. One study suggested that if the United States used ATDs for all immigrants in proceedings not convicted of serious crimes, the government could save over $\$ 1.4$ billion per year. ${ }^{94}$ Other studies suggest that the provision of counsel would additionally reduce detention costs. ${ }^{95}$

Finally, with respect to legal counsel, the Departments of Justice and Health and Human Services have instituted pilot programs to fund lawyers for unaccompanied children. ${ }^{96}$ The Administration also requested $\$ 50$ million in FY 2016 to fund additional lawyers for unaccompanied children. ${ }^{97}$ Extending these pilot programs to adult asylum seekers, and ultimately to all immigrants in proceedings, are important next steps to help ensure both compliance with the legal process and that individuals are afforded a fair opportunity to seek protection in the United States. 


\section{Endnotes}

${ }^{1}$ This paper focuses on asylum seekers who reach U.S. territory, rather than refugees whose status determinations take place outside of the United States. It does not specifically address unaccompanied minors, whose treatment raises distinct concerns.

${ }^{2}$ For a summary of U.S. expedited removal and reinstatement of removal provisions for asylum seekers, see Sara Campos and Joan Friedland, "Mexican and Central American Asylum and Credible Fear Claims: Background and Context," American Immigration Council, May 2014, http://www.immigrationpolicy.org/sites/default/files/docs/ asylum and credible fear claims final.pdf, p. 5-8.

${ }^{3}$ US Commission on International Religious Freedom (USCIRF), "Statement Of The US Commission On International Religious Freedom On Asylum: Credible Fear And Parole Processes," December 12, 2013 [hereinafter "USCIRF 2013 Credible Fear and Parole Processes"], http://www.uscirf.gov/sites/default/files/resources/ USCIRF-statement-asylum-credible-fear-rev4.pdf, p. 3; Donald Kerwin, "The Faltering US Refugee Protection System: Legal and Policy Responses to Refugees, Asylum-Seekers, and Others in Need of Protection," Refugee Survey Quarterly, 2013, 31:1-33, p. 19-20, 25-26.

${ }^{4}$ Cathryn Costello and Esra Kaytaz, Building Empirical Evidence into Alternatives to Detention: Perceptions of Asylum-Seekers and Refugees in Toronto and Geneva, Geneva: UNHCR, 2013 [hereinafter "Costello and Kaytaz 2013"] http://www.refworld.org/pdfid/51a6fec84.pdf, p.15.

${ }^{5}$ Alice Edwards, "Measures of First Resort: Alternatives to Immigration Detention in Comparative Perspective," Equal Rights Review, 2011, 7: 117-42, http://www.equalrightstrust.org/ertdocumentbank/ERR7 alice.pdf, p. 118.

${ }^{6}$ Costello and Kaytaz 2013, note 4, p. 8; Tom R. Tyler, Why People Obey The Law, Princeton: Princeton University Press, 2006; Tom R. Tyler and Jonathan Jackson, "Popular legitimacy and the exercise of legal authority: Motivating compliance, cooperation, and engagement," Psychology, Public Policy, and Law, Feb. 2014, 20(1): 78-95, http:// psycnet.apa.org/psycarticles/2013-40953-001; Nourit Zimerman and Tom R. Tyler, "Between Access To Counsel And Access To Justice: A Psychological Perspective," Fordham Urban Law Journal, 2010, 37: 473-507. Conversely, "if non-citizens believe that immigration officials and judges have acted unfairly...they will be less likely to comply with the system" after the unfair treatment. Jaya Ramji-Nogales, "Global Approach to Secret Evidence: How Human Rights Law Can Reform Our Immigration System," Columbia Human Rights Law Review, 2008, 39: 456-521, p. 484. This could result in a "spiraling effect" of noncompliance. Tom R. Tyler, "Procedural Justice, Legitimacy, and the Effective Rule of Law,” Crime \& Justice, 2003, 30: 283-357, p. 287.

${ }^{7}$ The 1996 laws followed a March 1996 U.S. government study that reported that 53 percent of non-detained noncitizens in removal proceedings appeared for their removal hearing, and only 11 percent of those ordered removed but not detained complied with an order of removal. U.S. Department of Justice, Office of the Inspector
General (DOJ/OIG), "Immigration and Naturalization Service, Deportation of Aliens After Final Orders Have Been Issued," I-96-03, March 1996, https://oig.justice.gov/reports/INS/e9603/; David A. Martin, "Two Cheers for Expedited Removal in the New Immigration Laws," Virginia Journal of International Law, 2000, 40: 673-704, p. 702 (Martin repeatedly discussed the DOJ Inspector General report with Congressional members and staff while Martin was INS General Counsel from 1995 to 1997). Those early studies underlying the mandatory detention laws, however, failed to specifically examine asylum seekers claiming relief in their proceedings. Michele Pistone, "Justice Delayed is Justice Denied: A Proposal for Ending the Unnecessary Detention of Asylum Seekers," Harvard Human Rights Journal, 1999, 12: 197-265, p. 228-29, 338-39. Those studies also predated modern supervision techniques (including but not limited to electronic tracking), and case management techniques that now assist respondents with appearing for hearings. Frances Kreimer, "Dangerousness on the Loose: Constitutional Limits to Immigration Detention as Domestic Crime Control," N.Y.U. Law Review, 2012, 87: 1485-1522, p. 1511.

${ }^{8}$ Vera Institute of Justice, "Testing Community Supervision for the INS: An Evaluation of the Appearance Assistance Program," New York: Vera Institute of Justice, 2000 [hereinafter, "Vera 2000"], http://www. vera.org/sites/default/files/resources/downloads/INS finalreport. pdf, p. 10, 27. Vera's study examined 83 asylum seekers, detained but released into supervision, compared to 214 asylum seekers detained and simply released. Ibid., p. 27. Vera's lower-supervision program was voluntary, and without mandatory reporting requirements. That program mainly involved orientation, information about compliance and noncompliance, and referrals to services upon request. Ibid., p. $17-18$.

9 Ibid., p. 31.

${ }^{10}$ Ophelia Field, with Alice Edwards, Alternatives to Detention of Asylum Seekers and Refugees, Geneva: UNHCR, 2006, http://www. refworld.org/docid/4472e8b84.html, p. 88, 95.

${ }^{11}$ U.S. Government Accountability Office (GAO), Alternatives to Detention: Improved Data Collection and Analyses Needed to Better Assess Program Effectiveness. Washington, DC: GAO, 2014 [hereinafter, "GAO 2014"] http://www.gao.gov/assets/670/666911.pdf, p. 30-31.

12 U.S. Department of Homeland Security (DHS), "Immigration and Customs Enforcement (ICE) Salaries and Expenses, Fiscal Year 2012 Congressional Budget Justification," http://www.dhs.gov/xlibrary/ assets/dhs-congressional-budget-justification-fy2012.pdf, p. 44; Lutheran Immigration and Refugee Service (LIRS), Unlocking Liberty: A Way Forward for US Immigration Detention Policy, Baltimore, MD: Lutheran Immigration and Refugee Service, 2011 [hereinafter, "LIRS 2011"] http://www.lirs.org/wp-content/uploads/2012/05/ RPTUNLOCKINGLIBERTY.pdf, p. 14.

${ }^{13}$ Edwards 2011, note 5, p. 124; Immigration Detention Coalition (IDC), 
Case management as an alternative to immigration detention: The Australian Experience, Melbourne, Australia: Immigration Detention Coalition, 2009, http://idcoalition.org/wp-content/uploads/2009/06/ casemanagementinaustralia.pdf, p. 1.

${ }^{14}$ Costello and Kaytaz 2013, note 4, p. 11. In 2012, the Oxford researchers conducted a qualitative study for UNHCR involving 22 interviews of Toronto asylum seekers, and 30 interviews of Geneva asylum seekers. The sample was fairly representative, but too small to draw quantitative conclusions. Ibid. UNHCR's findings echo and draw upon Jesuit Refugee Services' qualitative interviews of six families in a Belgian alternative-to-detention program, nine unaccompanied minors in Germany, and 10 migrants in the United Kingdom. Jesuit Refugee Service Europe (JRS), From Deprivation to Liberty: Alternatives to Detention in Belgium, Germany and The United Kingdom, Brussels: JRS Europe, 2011 [hereinafter, “JRS 2011”], https://jrseurope. org/assets/Sections/Downloads/JRS\%20EUR\%20ATD\%20report FINAL 13Dec2011.pdf, p. 5-6.

${ }^{15}$ Costello and Kaytaz 2013, note 4, p. 12.

${ }^{16}$ Ibid., p. 13.

17 Ibid.

18 Ibid., p. 12.

19 Ibid., p. 15.

${ }^{20}$ Donald Kerwin, "Legalization of U.S. Unauthorized Residents: A Rule of Law or Access to Justice Issue?" Huffington Post, October 30, 2013, http://www.huffingtonpost.com/donald-kerwin/legalization-of-usunauth b 4175108.html.

${ }^{21}$ Costello and Kaytaz 2013, note 4, p. 15.

${ }^{22}$ Ibid.

${ }^{23}$ Ibid. p. 12.

${ }^{24}$ Vera 2000, note 8, p. 56.

${ }^{25}$ Costello and Kaytaz 2013, note 4, p. 24; Vera 2000, note 8, p. 7 (calling representation by counsel one of the most consistent factors that determines whether a noncitizen will comply with proceedings); JRS 2011, note 14, p. 38-40.

${ }^{26}$ Ibid., p. 16.

${ }^{27}$ Vera 2000, note 8, p. 60; Costello and Kaytaz 2013, note 4, p. 33 ("I want to do the right thing").

${ }^{28}$ Vera 2000, note 8, p. 55 ("Asylum seekers were particularly confused at the time of apprehension").

${ }^{29}$ Costello and Kaytaz 2013, note 4, p. 13.
${ }^{30}$ Liesbeth Schockaert, "Alternatives to detention: open family units in Belgium," Forced Migration Review, 2013, 44: 52-55, http://www. fmreview.org/detention/schockaert\#sthash.r7S6zl3v.dpuf, p. 52; Philip Amaral, "Immigration Detention: Looking at the Alternatives," Forced Migration Review, 2013, 44: 40-42, http://www.fmreview.org/ detention/amaral, p. 41-42.

${ }^{31}$ Vera 2000, note 8, p. 59.

${ }^{32}$ American Immigration Council, "Taking Attendance: New Data Finds Majority of Children Appear in Immigration Court," July 2014, http:// immigrationpolicy.org/just-facts/taking-attendance-new-data-findsmajority-children-appear-immigration-court.

${ }^{33}$ Vera 2000, note 8, p. 53; Leo Chavez, "The Power of Imagined Community: The Settlement of Undocumented Mexicans and Central Americans in the United States," American Anthropology, 1994, 96: 5273.

${ }^{34}$ Costello and Kaytaz 2013, note 4, p. 18.

${ }^{35}$ Ibid.

${ }^{36}$ Vera 2000 , note 8 , p. $15-17$.

${ }^{37}$ Vera 2000 , note 8, p. 53, 58-59.

${ }^{38}$ Ibid, p. 58.

${ }^{39}$ Ibid.

40 Ibid., p. 59.

${ }^{41}$ See Center for Victims of Torture (CVT), Torture Abolition and Survivor Support Coalition, International (TASSC) and Unitarian Universalist Service Committee (UUSC), Tortured \& Detained: Survivor Stories of US Immigration Detention, 2013 [hereinafter "CVT et al. 2013"] http://www.cvt.org/sites/cvt.org/files/Report TorturedAndDetained Nov2013.pdf, p. 7 ("many survivors of torture seeking asylum in the United States" arrive with "only the clothes on their back").

${ }^{42}$ See, U.S. Immigration and Customs Enforcement (ICE), "Parole of Arriving Aliens Found to Have a Credible Fear of Persecution or Torture," 8 December 2009 [hereinafter, "ICE 2009"] http://www.ice. gov/doclib/dro/pdf/11002.1-hd-parole of arriving aliens found credible fear.pdf, p. 7; CVT et al. 2013, note 41, p.7; DHS/OIG (US Department of Homeland Security, Office of the Inspector General), U.S. Immigration and Customs Enforcement's Alternatives to Detention (Revised), Washington, DC: US Department of Homeland Security, 2015, https://www.oig.dhs.gov/assets/Mgmt/2015/OIG 15-22 Feb15. pdf, p. 22.

${ }^{43}$ Costello and Kaytaz 2013, note 4, p. 14.

${ }^{44}$ Vera 2000, note 8, p. 28. 
45 Ibid., p. 59.

${ }^{46}$ Ibid., p. 61.

${ }^{47}$ MRS/USCCB (Migration and Refugee Services/United States Conference of Catholic Bishops) and CMS (Center for Migration Studies), "Unlocking Human Dignity: A Plan to Transform the US Immigrant Detention System," Journal on Migration and Human Security, 2015 [hereinafter, "MRS/USCCB and CMS 2015”], 3 (2): 159204, p. 171-174; U.S. Commission on International Religious Freedom (USCIRF), Assessing the U.S. Government's Detention of Asylum Seekers: Further Attention Needed to Fully Implement Reforms, April 2013 [hereinafter, "USCIRF, Assessing Detention of Asylum Seekers 2013"], http://www.uscirf.gov/sites/default/files/resources/ERS-detention $\% 20$ reforms\%20report\%20April\%202013.pdf; American Bar Association (ABA), "ABA Civil Immigration Detention Standards," Washington, DC: American Bar Association, 2012, http://www.americanbar.org/groups/ public services/immigration/civilimmdetstandards.html.

${ }^{48}$ American Immigration Council, "Way Too Long: Prolonged Detention in Border Patrol Holding Cells, Government Records Show," June 10, 2015, http://immigrationpolicy.org/just-facts/way-too-longprolonged-detention-border-patrol-holding-cells-governmentrecords-show, p. 2 (collecting reports of poor conditions), citing, e.g., Americans for Immigrant Justice (AIJ), "The 'Hieleras': A Report on Human \& Civil Rights Abuses Committed by US Customs \& Border Protection," 2013, http://www.aijustice.org/the-hieleras-a-reporton-human-civil-rights-abuses-committed-by-u-s-customs-borderprotection-2l.

${ }^{49}$ Dora Schriro, Immigration Detention Overview and Recommendations, Washington, DC: U.S. Department of Homeland Security, Immigration and Customs Enforcement, 2009, http://www. ice.gov/doclib/about/offices/odpp/pdf/ice-detention-rpt.pdf, p. 2-3.

${ }^{50}$ Michael Flynn, "Who Must Be Detained? Proportionality as a Tool for Critiquing Immigration Detention Policy," Refugee Survey Quarterly, 2012, 1: 1-29, p. 23; USCIRF, Assessing Detention of Asylum Seekers 2013, note 47, p. 1.

${ }^{51}$ Physicians for Human Rights (PHR), Punishment before Justice: Indefinite Detention in the US. Washington, DC: Physicians for Human Rights, 2011 [hereinafter, "PHR 2011"], https://s3.amazonaws.com/ PHR Reports/indefinite-detention-june2011.pdf, p. 7-11.

52 Ibid, p. 11.

${ }^{53}$ Physicians for Human Rights (PHR) and Bellevue/NYU Program for Survivors of Torture, "From Persecution to Prison: The Health Consequences of Detention for Asylum Seekers," 2003, p. 2.

${ }^{54}$ PHR 2011, note 51, pp. 26-27; CVT et al. 2013, note 41, p. 11.

${ }^{55}$ Soorej Jose Puthoopparambil, Beth Maina-Ahlberg, and Magdalena Bjerneld, "'A prison with extra flavours': experiences of immigrants in Swedish immigration detention centres," International Journal of Migration, Health and Social Care, 11(2): 73-85 2015 [hereinafter "Puthoopparambil et al. 2015"], http://www.emeraldinsight.com/doi/ full/10.1108/IJMHSC-10-2014-0042; Soorej Jose Puthoopparambil, Beth Maina-Ahlberg, and Magdalena Bjerneld, "Do higher standards of detention promote well-being?" Forced Migration Review, 44: 39, 2013 [hereinafter "Puthoopparambil et al. 2013"], http://www.fmreview. org/detention/puthoopparambil-et-al\#sthash.qtDveW84.dpuf, p. 39.

${ }^{56}$ Janet Cleveland, "Psychological harm and the case for alternatives," Forced Migration Review 44: 7-8, 2013, http://www.fmreview.org/ detention/cleveland\%20\#sthash.kZt8o3pC.dpuf, p. 7.

${ }^{57}$ Roque Planas, "Mother Who Attempted Suicide In Family Detention Center Deported," Huffington Post, June 9, 2015, http://www.huffingtonpost.com/2015/06/09/mother-suicidedeported n 7545934.html (woman attempted suicide while detained at Karnes center); Esther Yu-Hsi Lee, "Migrant Woman Attempted Suicide Minutes After Realizing She Can't Afford Her Own Release," ThinkProgress, March 12, 2015, http://thinkprogress.org/ immigration/2015/03/12/3633003/honduran-woman-attemptssuicide-over-high-bond/ (woman attempted suicide while detained at Dilley center).

${ }^{58}$ Roque Planas, "Some Hunger-Striking Mothers Were Put In Isolation At Karnes Immigrant Detention Center, Lawyers Say," Huffington Post, April 2, 2015, http://www.huffingtonpost.com/2015/04/02/karneshunger-strike n 6994436.html.

59 John Stanton, "Undocumented Immigrant Families Protest Conditions At Detention Facility During Congressional Tour," BuzzFeed, June 23, 2015, http://www.buzzfeed.com/johnstanton/ undocumented-immigrant-families-protest-conditions-at-detent\#. dyZ4BI6Xzp (protest during Congressional visit to Karnes center).

${ }^{60}$ PHR 2011, note 51, p. 7.

${ }^{61}$ Puthoopparambil et al. 2013, note 55, p. 39; Puthoopparambil et al. 2015, note 55; USCIRF, Assessing Detention of Asylum Seekers 2013, note 47, p. 2; US Commission on International Religious Freedom (USCIRF), Report on Asylum Seekers in Expedited Removal, Volume I: Findings and Recommendations, Washington, DC: USCIRF, 2005 [hereinafter, "USCIRF 2005”], http://www.uscirf.gov/sites/default/files/ resources/stories/pdf/asylum seekers/Volume I.pdf, p. 68.

${ }^{62}$ Associated Press, "Complaint: Family Detention Can Lead to Psychological Harm," New York Times, June 30, 2015, http://www. nytimes.com/aponline/2015/06/30/us/ap-us-immigration-detentionmental-health.html. As the Dean of the University of Texas-Austin School of Social Work said, "They have tried to make these places look and feel better but ultimately they are still behind walls and they don't have freedom." Ibid.

${ }^{63}$ American Immigration Council, "Immigrants Held for Days in Freezing, Unsanitary Cells File Class-Action Lawsuit,” June 10, 2015, http://www.americanimmigrationcouncil.org/newsroom/release/ immigrants-held-days-freezing-unsanitary-cells-file-class-action- 
$\underline{\text { lawsuit. }}$

${ }^{64} 8$ U.S.C. § 1362 (2012), https://www.law.cornell.edu/uscode/ text/8/1362.

${ }^{65}$ New York Immigrant Representation Study (NYIRS), "Accessing Justice: The Availability and Adequacy of Counsel in Immigration Proceedings," Cardozo Law Review, 2011, 33: 357-416 [hereinafter, "NYIRS 2011"], p. 373-77; Peter L. Markowitz, "Barriers to Representation for Detained Immigrants Facing Deportation: Varick Street Detention Facility, a Case Study," Fordham Law Review, 2009, 78: 541-575, http://ir.lawnet.fordham.edu/cgi/viewcontent. cgi?article $=4477 \&$ context=flr, p. 556-57.

${ }^{66}$ Markowitz, note 65, p. 559-60; Legal Action Center, Behind Closed Doors: An Overview of Restrictions on Access To Counsel May 2012, http://www.legalactioncenter.org/sites/default/files/docs/lac/ Behind Closed Doors 5-31-12.pdf, p. 11-12; New York Immigrant Representation Study (NYIRS), "Accessing Justice II: A Model for Providing Counsel to New York Immigrants in Removal Proceedings," December 2012, p. 15-16, http://www.cardozolawreview.com/content/ denovo/NYIRS ReportIl.pdf.

${ }^{67}$ NYIRS 2011, note 65, p. 370 n. 27, 379, 387-88, 405 n. 107.

${ }^{68}$ Jaya Ramji-Nogales, Andrew I. Schoenholtz and Philip G. Schrag, "Refugee Roulette: Disparities in Asylum Adjudication," Stanford Law Review, 2007, 60: 295-411, p. 340.

${ }^{69}$ NYIRS 2011, note 65, p. 384-85.

${ }^{70}$ Philip G. Schrag \& Michele R. Pistone, "The New Asylum Rule: Not Yet A Model Of Fair Procedure," Georgetown Immigration Law Journal, 1997, 11: 267-301, p. 287.

${ }^{71}$ Rachel D. Settlage, "Affirmatively Denied: the Detrimental Effects of a Reduced Grant Rate for Affirmative Asylum Seekers," Boston University International Law Journal, 2009, 27: 61-113, https://www.bu.edu/ law/central/jd/organizations/journals/international/volume27n1/ documents/Settlage.pdf, p. 83.

${ }^{72}$ Ibid., at p. 93; USCIRF 2005, note 61, p. 7.

${ }^{73}$ USCIRF 2013 Credible Fear and Parole Processes, note 3, p. 2; Pistone, note 7, p. 224; MRS/USCCB and CMS 2015, note 47, p. 168, 172.

74 USCIRF 2005, note 61, p. 52.

${ }^{75}$ USCIRF, "Asylum Withdrawals By Custody Status By Fiscal Year completed," http://www.uscirf.gov/sites/default/files/resources/ stories/pdf/asylum seekers/EOIR_Tables 5-7.pdf, p. 670.

${ }^{76}$ U.S. Citizenship and Immigration Services (USCIS), "Credible Fear Workload Report Summary," 2014, http://www.uscis.gov/sites/default/ files/USCIS/Outreach/Upcoming\%20National\%20Engagements/PED Credible Fear and Reasonable Fear FY14 Q4.pdf, p. 2, 5.

${ }^{77}$ As of January 2014, the U.S. Citizenship and Immigration Service (USCIS) reported that the average time for a reasonable fear decision was 68 days, down from 113 days as of December 2012. USCIS Asylum Division, "Asylum Division Quarterly Stakeholder Meeting," Washington, DC: US Citizenship and Immigration Services Asylum Division, January 28, 2014 [hereinafter, "USCIS Asylum Division 2014"], http://www.uscis.gov/sites/default/files/USCIS/Outreach/ Notes\%20from\%20Previous\%20Engagements/FINAL Asylum Quarterly Stakeholder Meeting Notes January282014.pdf, p. 13; USCIS Asylum Division, "Asylum Division Quarterly Stakeholder Meeting," Washington, DC: US Citizenship and Immigration Services Asylum Division, December 6, 2012, http://www.uscis.gov/outreach/ notes-previous-engagements/asylum-division-quarterly-stakeholdermeeting-3, p. 6. Meanwhile, DHS officials reported in December 2013 that initial mandatory detention pending a credible fear determination currently lasted approximately 27 days on average then. U.S. Department of Homeland Security (DHS), "Combined DHS Written Testimony for a Hearing on 'Asylum Abuse: Is it Overwhelming our Borders?' Before the House Committee on the Judiciary," December 12, 2013. http://judiciary.house.gov/?a=Files.Serve\&File id=E9043D83E429-4D21-9621-C681C6499251, p. 4. The DHS officials reported that during FY 2013, "the average number of days between the date when an individual was detained in the [expedited removal] process and the date the individual was referred to the USCIS Asylum Division for the scheduling of a credible fear interview was 19 days," and that from June 2013 to December 2013, the USCIS credible fear screening process took an average of 8 days. Ibid. The latter USCIS screening time has since improved, however. From October 2013 to January 2014, the USCIS credible fear interview took an average of 4.7 days. USCIS Asylum Division 2014, p.13.

${ }^{78}$ MRS/USCCB and CMS 2015, note 47, p. 189-94.

${ }^{79}$ See Border Security, Economic Opportunity, and Immigration Modernization Act, $113^{\text {th }}$ Cong., S. 744, https://www.congress.gov/ bill/113th-congress/senate-bill/744/text, $§ 3715$ (requiring DHS to establish alternatives to detention with NGOs); § 3717(a) (establishing additional detention protections, such as shifting the burden on DHS to show that "no conditions... will reasonably assure the appearance of the alien as required and the safety" of the community); $\S 3502$ (c) (requiring appointed counsel for "particularly vulnerable," unaccompanied children and the mentally disabled); § 3716 (establishing additional detention conditions oversight).

${ }^{80}$ American Immigration Council, "Help Us End Family Detention," http://www.americanimmigrationcouncil.org/help-us-end-familydetention; MRS/USCCB and CMS 2015, note 47, p. 194.

${ }^{81}$ American Immigration Council, "Homeland Security Secretary Announces Changes to Family Detention Policies," June 24, 2015, http://www.americanimmigrationcouncil.org/newsroom/release/ homeland-security-secretary-announces-changes-family-detentionpolicies.

${ }^{82}$ American Immigration Council, "Release of Refugee Families is Long-Overdue Step," July 13, 2015, http://www. americanimmigrationcouncil.org/newsroom/release/release-refugeefamilies-long-overdue-step.

${ }^{83}$ GAO 2014, note 11, p. 13-14, 16; MRS/USCCB and CMS 2015, note 47, 
p. 188.

${ }^{84}$ Rutgers School of Law-Newark Immigrant Rights Clinic and American Friends Service Committee, Freed But Not Free: A Report Examining the Current Use of Alternatives to Immigration Detention, 2012, http://www.law.newark.rutgers.edu/files/FreedbutnotFree.pdf, p. 6-9 (ICE employs its ISAP program for individuals in formal removal proceedings, under 8 U.S.C. $\S 1226(a)$, or after a removal order). For parolees, DHS regulations allow ICE officers to consider "[a]greement to reasonable conditions (such as periodic reporting of whereabouts)." 8 C.F.R. $\S 212.5$ (d)(3). Also, ICE's parole guidance for those who enter at ports of entry and pass credible fear directs officers to consider whether an alternative to detention program would provide "reasonable assurances" against flight. ICE 2009, note 42, p. 7.

${ }^{85} \mathrm{GAO} 2014$, note 11, p. 26. ISAP's full-service program involves monitoring (either by GPS or telephone), home and office visits, and a caseworker who provides individual assessment and referrals to services such as pro bono legal assistance. ISAP's technology-only program involves monitoring only. Ibid., p. 10-11; DHS/OIG, note 42, 2015, p. 4.

${ }^{86}$ Maria Sacchetti, "Newest illegal immigrants face more scrutiny than many criminals," Boston Globe, July 2, 2015, https:// www.bostonglobe.com/metro/2015/07/02/asylum-seekersoften-monitored-immigration-more-strictly-than-criminals/ PZ7HOpIWQJdBVhIOvUOMAL/story.html.

${ }^{87}$ Bethany Carson, Grassroots Leadership, Letter to editor, "Immigration detention centers," The Monitor, July 1, 2015, http:// www.themonitor.com/letters-on-immigration-detention-centersand-helping-veterans-exposed-to/article 88e5ee34-2035-11e5-9ceb3f20449bb7e0.html; Julie Turkewitz, "Immigrant Mothers Released From Holding Centers, but With Ankle Monitors," New York Times, July 29, 2014, http://www.nytimes.com/2014/07/30/nyregion/immigrantmothers-released-from-holding-centers-but-with-ankle-monitors. $\underline{\text { html. }}$.

${ }^{88}$ Latino Rebels, "Central American Mom Shares Detention Nightmare Even After Her Release," May 22, 2015, http://www.latinorebels. com/2015/05/22/central-american-mom-shares-detention-nightmareeven-after-her-release/.

${ }^{89}$ Most prominently, the Vera Institute of Justice's Appearance Assistance Program pilot from 1997 to 2000. Vera 2000, note 8. Other community supervision programs have been implemented by Lutheran Immigrant Refugee Service and Catholic Charities. LIRS 2011, note 12, p. 26-27, 31-32; Lutheran Immigrant and Refugee Service (LIRS), “Community Support Partners," 2013, http://lirs.org/our-work/ partnership/service-partners/access-to-justice-partners/communitysupport-partners/; MRS/USCCB and CMS 2015, note 47, p. 170.

90 "Family Case Management Services," FedBizOpps.Gov, https://www. fbo.gov/index?s=opportunity\&mode=form\&id=ce539b68d84cd9aa9f5 9ea99c906b56a\&tab=core\& cview=1 (Baltimore/Washington); "Family Case Management Services-NY," FedBizOpps.Gov, https://www.fbo. gov/index?s=opportunity\&mode=form\&id=ec67398fe $25 \mathrm{f} 07 \mathrm{~d} 71361 \mathrm{dc0}$ 9c11a2394\&tab=core\& cview=1 (New York City and Newark); "Family Case Management Services-Miami," FedBizOpps.Gov, https://www. fbo.gov/index?s=opportunity\&mode=form\&id=a9cc4a72fd8a46d51 65d40da4a1ec68b\&tab=core\& cview=1; "Family Case Management Services-CHI," FedBizOpps.Gov, https://www.fbo.gov/index?s=oppo rtunity\&mode $=$ form\&id $=3278335$ b5d 772 d1 beaea5b237590778a\&tab =core \& cview=1 (Chicago); "Family Case Management Services-LA," FedBizOpps.Gov, https://www.fbo.gov/index?s=opportunity\&mode=fo $\underline{\text { rm\&id }=8009 f 850 f c 1 b 7 f 29 f 5915 \mathrm{~d} 3 \mathrm{da} 81 \mathrm{f} 72 \mathrm{~d} 2 \& \mathrm{tab}=\mathrm{core} \& \mathrm{cview}=1}$ (Los Angeles).

${ }^{91}$ MRS/USCCB and CMS 2015, note 47, p. 184-86.

${ }^{92}$ GAO 2014, note 11, p. 18.

${ }_{93}$ U.S. DHS, "Congressional Budget Justification FY 2016," Feb. 2, 2015, http://www.dhs.gov/publication/congressional-budget-justificationfy-2016.

${ }^{94}$ National Immigration Forum, "The Math of Immigration Detention," August 2013, http://immigrationforum.org/blog/ themathofimmigrationdetention/.

95 John D. Montgomery, "Cost of Counsel in Immigration: Economic Analysis of Proposal Providing Public Counsel to Indigent Persons Subject to Immigration Removal Proceedings," NERA Economic Consulting, May 2014, http://www.nera.com/content/dam/nera/ publications/archive2/NERA Immigration Report 5.28.2014.pdf.

${ }^{96}$ American Immigration Council, "A Guide to Children Arriving at the Border: Laws, Policies and Responses," June 2015, http:// immigrationpolicy.org/sites/default/files/docs/a guide to children arriving at the border and the laws and policies governing our response.pdf, p. 8 \& n. 48, 49 (summarizing pilot programs), p. 14 \&n. 123 (summarizing various proposals to provide counsel).

97 U.S. DHS, “Congressional Budget Justification FY 2016," Feb. 2, 2015, http://www.dhs.gov/publication/congressional-budget-justificationfy-2016. 